Crime, Law \& Social Change 21: 183-190, 1994.

(C) 1994 Kluwer Academic Publishers. Printed in the Netherlands.

\title{
Rethinking critical criminology
}

\author{
A panel discussion
}

\author{
RENE VAN SWAANINGEN ${ }^{1}$ and IAN TAYLOR ${ }^{2}$ \\ ${ }^{1}$ Erasmus University, 3000 DR Rotterdam, The Netherlands; ${ }^{2}$ University of Salford, \\ M5 4WT, UK
}

\begin{abstract}
This paper takes the form of a report on the panel discussion held at the conclusion of the 1992 meetings of the European Group for the Study of Deviance and Social Control in Padua in September 1992. In the light of a perceived crisis of relevance for earlier, 1970s notions of critique in criminology, and in the context of a conference dedicated to the theme of human rights in a uniting Europe, eight panellists from Italy, England, and Canada via Ireland debated their different versions of the project of critical criminology in the last years of the twentieth century. Each of these presentations is summarised here, and an attempt is made to recognise the emergence of a debate between a "human rights criminology", eversensitive to the possibilities of repression and control in Fortress Europe, and an alternative perspective, predicated perhaps on some notion of Social Defence and a realist programme of crime prevention and control across free market Europe.
\end{abstract}

Critical criminology emerged in the 1970 s as a competing paradigm to the dominant form of administrative criminology. But after having paved the way for an alternative agenda, critical criminology was quite generally described, by the end of the $1980 \mathrm{~s}$, as being in crisis. Whether one wanted to blame "the end of history", the demise of the grand narratives of progress and emancipation, the bankruptcy of socialism or the victory of individualistic consumerism, the project of critical criminology does not really seem to fit any more in the post- 1984 world. If critical criminology is to re-connect to the times, the issue posed is which of its concepts need revision, which ones had better be forgotten altogether and which ones have kept their validity? A first attempt to re-evaluate the position of criminology was made in 1991 in the context of the Law and Society meetings in Amsterdam at a session specially organised by Stan Cohen, Willem de Haan, Elena Larrari, Fritz Sack and Karl Schumann. Some twenty criminologists from various different European societies, and some from North America, attended a workshop entitled Transferring Progressive Criminology, with the avowed intention of examining the 
issues involved in the transfer of critical concepts across cultures. ${ }^{1}$ In their different presentations, representatives of the organising group highlighted the problem of whether it was possible to identify universal criteria, from the great variety of "progressive" perspectives within criminology, that could be applied across different countries or different political and social situations. There was discussion, for example, of the Israeli use of torture during the Intifada as an instance of state repression (Stan Cohen); the inapplicability of American labelling theory when it was transferred, during the early 1970 s, to the Italian context (Dario Melossi) and also the counter-productive character of "the critique of social control" (for example, the "net-widening" effects of non-custodial sanctions) when it was applied to countries (like Spain) with alarming conditions in its existing prisons (and hardly any kind of alternative to them) (Elena Larrari). Following these introductory discussions, there were further contributions on the problem of "transferring progressive criminology", from Carol Smart (Leeds, England) with respect to the issue of gender; Lech Falandysz (Warsaw, Poland) in respect of post-Communism, and Dirk van Zyl Smit (Cape Town, South Africa) with regard to the context of the continuing struggle against apartheid.

Different as these concrete examples may have been, one underlying theoretical issue could be identified. There was a marked sense that the use of a conceptual focus on social justice and civil liberty and on legal guarantees for the protection of human rights could prevent a collapse into a new value-relativism, but this was also coupled with the recognition that the specific implementation of this conceptual and political programme could not be globalised.

The plan to continue the 1991 initiative was taken up by Guiseppe Mosconi, Rene van Swaaningen and Ian Taylor. The XXth conference of the European Group for the Study of Deviance and Social Control, which was due to meet in Padua in September 1992, dealing with the theme of human rights in a uniting Europe, was thought to be an appropriate occasion for continuing the debate, particularly in respect of the problem of universalistic versus relativistic conceptions of progressive or critical criminology. The European Group, in its turn, agreed to hold a specific workshop within the Padua conference around these themes. Focussing, as such a workshop would, on the ongoing problems confronting critical criminologists throughout Europe, there was also a sense in which this workshop could potentially touch on the future trajectory of the European Group itself. ${ }^{2}$

The Padua conference of the European Group was attended by some 100 delegates from all over Europe, and the workshop on the Future of Critical Criminology was held on the final day of the conference. Rene van Swaaningen chaired a panel (consisting of John Lea (Middlesex, England), Maeve 
McMahon (Toronto), Pio Marconi (Rome), Guiseppe Mosconi (Padua), Massimo Pavarini (Bologna), Eligio Resta (Bari), Vincenzo Ruggiero (Middlesex, England/Torino) and Ian Taylor (Salford, England) to debate the trajectory of critical criminology in the last decade of the twentieth century. Without being able to do justice to these presentations, we thought it would be useful to try and present a brief summary of the topics raised by the panel and also by some of the people who intervened during audience discussion.

Ian Taylor began by referring to the extraordinary increases in the numbers of crimes known to the police in the U.K., the U.S., and, indeed, in the old Soviet Union. Even in France, where the Social Crime Prevention programmes has brought about some decrease in the problem in the late 1980s, there were now reports of significantly renewed increases, both of crimes against property and crimes against the person. It was no longer good enough for critical criminologists to consign these problems to some later moment "after the revolution" or to see them merely as an artifact of the imposition of social control and discipline, after the fashion of the Foucaultian problematic. It was also inadequate for critical criminologists to retreat into a monocausal form of economic determinism as an explanation of the contemporary crime problem: the work of Habermas, particularly his critique of free market society from a perspective insisting on a Public Interest and a Public Sphere, provided a much more powerful link between the macro-analysis of crime as an overall social issue and the micro-analysis of individual instances. Habermas is important for critical criminologists, however, precisely because his critique of current conditions (the free market society and its celebration of individualistic consumerism) is not merely dismissive: his plea is not for the suppression of individualism, or desire, or style, but rather for the organisation of such pleasures within the broad parameters of a society organised around notions of Public Provision and a democratic, universalistic conception of citizenship.

In what he called "a small manifesto of critical criminology", John Lea raised the issue as to whether there really was that was so new about this era as to justify the revision of the concepts and programmes of the critical criminological project. The major issues of the day - racism, unemployment etc-are very old. What had been new in the post-war period had been the Cold War and the Welfare State. Both of these now belonged to history. What is left for the Left is to take rights seriously. This also implies, according to Lea, taking crime seriously, especially if crime is to be defined as the violation of human rights. ${ }^{3}$ But some things have changed, and critical criminology should take these into consideration. In particular, the privatisation of control that was developing throughout the criminal justice system was an important issue, closely connected up to a perceptible militarisation of "the private 
sphere". It was important to identify and to challenge the silence on these developments, and the general abstentionism, of administrative criminology, with its discursive focus on crime prevention and its avoidance of discussion of the broad causes of crime.

Maeve McMahon wondered whether the overall orientation of critical criminology to such a general theory or to a generalised political critique has been very fruitful. So, for example, the categorical critique of almost any criminal initiative as "an expansion of State social control" has undermined the possibility of constructive opposition, and the tendency to look for problems rather than opportunities has probably undermined many community groups working on particular crime problems (for example, in respect of domestic violence). In insisting that critical criminology must connect with people's direct experience, McMahon pleaded for greater attention being paid to a micro-politics. Classical topics like police brutality should remain a key focus, but they should be addressed at the level of personal or community experience. Speaking about a macro-politics, at least at the level of the national setting, may have become an anachronism. So, for example, the changes occurring in what is now increasingly called "Fortress Europe" are embedded in broader structural changes - in which Brussels and Strasbourg are not so much the key symbols, but rather Somalia and Yugoslavia. If we can to make these global changes visible, then some modification of our concepts of power and power-relations may be in order.

For Pio Marconi, the crisis of critical criminology should not be seen as a fundamental crisis, after the fashion in which Rosa Luxemburg once spoke (mistakenly) about the crisis of capitalism. Critical criminology is now confronting certain problems of a technical character, but this does not compromise the basic project. We can still explain a lot using the theoretical starting-point of critical criminology (namely, the refinement of traditional Marxist conflict theory with an approach focussed on deviance and identity). The main crisis in Europe at present is indeed a crisis of identity: in Eastern Europe as well as in liberal capitalist states like Italy, this crisis of identity is occurring at the level of the state itself. In Italy, indeed, this identity crisis manifests itself in a struggle between the State and the Mafia. This fundamental issue, of legitimacy and identity, should remain the key object of critical criminology. So the tools with which critical criminology proceeds may need to be replaced, but not the premisses of its approach as such.

Guiseppe Mosconi, on the other hand, did want to question some of the theoretical starting points of critical criminology. Firstly, the very idea of "deviance" pre-supposed a well-organised society with clear and stable rules. Such societies are becoming increasingly scarce. Second, the idea of "social control" is itself also an idea in crisis, for rather the same reasons. The idea of 
social control has traditionally connoted assumptions about the manageability of social problems, and there is increasingly evidence that this assumption cannot be sustained. And, thirdly, the theoretical battle between abolitionism, realism and "neo-Kantian guaranteeism" is in one sense over: it is the subject matter of crime itself which excites most attention, to which different social groups respond in markedly different fashions.

The proclamation of the death of criminology is nothing new, according to Massimo Pavarini. Enrico Ferri signalled it at the end of the nineteenth century. Moreover, the continuous proclamation of criminology's demise is, in any case, a sign of strength not of weakness: this is how the stagnation of the discipline is prevented. Criminological discourse has also always had an artificial nature, with its uneven relation to conventional or legal concepts of crime. Critical criminology, in particular, could take credit for dismantling these conventional definitions, and for arguing that the discourses of crime are really discourses about youth, gender or race. All of these problems certainly have a material basis, but, ironically, Pavarini went on to argue, it may be that we can expect more by way of resolving these problems in the 1990s through legal activism than from participation in social activism. Critical criminology should not orient itself in a meta-disciplinary fashion to the exploration of Law and Philosophy.

As a result of his own disappointment with the critical criminological project, by contrast, Eligio Resta argued for its complete demolition. The key paradox is that whilst critical criminology has successfully undermined the legal concept of crime, it has not been able to challenge the idea of an autonomous criminological discipline and field. Within criminology itself, any notion of conflict has now disappeared. Issues to do with capital and the State have been emphasised to the exclusion of the individual and identity. Nietzsche was right, not Marx: everybody is important, because noone is. The idea of freedom has become so abstract that rights actually to not count. In the past ten years, legal philosophy has been more critical with respect to these developments than has criminology, and maybe we should move in this direction as well.

According to Vincenzo Ruggiero, the very adjective "critical" has become too demanding, whilst, in the meantime, the subject-matter of criminology has itself become less and less well-defined. Concepts are borrowed from various fields of knowledge and then "hi-jacked". The objective of critical criminology has become almost akin to the limitation of all human suffering. The title of one particular journal, Contemporary Crises, perfectly summarised the unfocussed and rather a-historical focus of this version of criminological critique. Of course, the burdens have proven to be more than any one person (or journal) can carry; and, furthermore, very little real expertise has 
been forthcoming. Any criminologist studying organised crime, for example, from within this general critical perspective, has had to try to claim an expertise in everything from political science to political economy. Maybe the future of critical criminology lay in a more modest set of objectives, and the development of a specific, unchallengeable expertise.

The problems in the critical criminological project identified by the different panels could be summarised as falling into three different areas - first, the definition of criminology as such; second, the move from a macro-political level of analysis to more direct experience; and, finally, the attempt to make sense of a perceived shift in the nature of economic relations. Questions from the audience tended to focus on the first two areas.

Tamar Pitch (Perugia) pointed out how the panel had been speaking from two distinctly different traditions of criminology. In the Anglo-Saxon world, criminologists have formed a caste of so-called experts with a set of instrumental objectives (which can be held up for discussion and critique), but in the Italian context, for example, there has never been any such a specialised caste of criminologists. In these circumstances, critique is a non-issue. In this respect, Ruggiero's analysis might apply to the British situation, but it does not fit the Italian one. Ramiro Sagarduy (Rosario, Argentina) wanted critical criminology to opt for an expertise that did justice to its claim to be critical: critical criminologists ought legitimately to strive to become experts in the abuses of the state. For Lode van Outrive (Louvain, Belgium), however, the whole, painful discussion of the "identity" of critical criminology was rather silly. What's in a name, he asked. There are different subject-matters, and we have different criminological theoretical approaches to explain them. Phenomenological theories still offer good insights with respect to the micro-dynamics of crime, Marxian theory with respect to macro-politics and Foucaultian and Habermassian theories are useful for exploring the inter-connectedness. There is little need for simple conflict theory or, for that matter, the philosophical urge to forget criminology altogether. There is a need for the critical analysis of a variety of pressing social problems, and what you call the versions of critique is not always the most important issue. There was a marked interest, during discussion, in the shift towards a more micro-orientation that had been alluded to by several of the panel speakers. For many participants, including Paddy Hillyard (Bristol, England) and Bill Rolston (Belfast, Northern Ireland) this shift to a micro-orientation seemed primarily to be interpreted as suggesting a new kind of political role for critical criminologists - in particular local struggles in Europe, and, in this sense, a role, perhaps, for the European Group itself. For others, this direct move to a politics (and, indeed, a politics that seemed very much an affirmation of the politics of the European Group during the 1980s) was not really so clearly warrantable. It is noticeable how feminist 
criminology has found it difficult to sustain an unambiguous or essentialist orientation to policy struggles in the early 1990s, and how the whole field is now engaged in a complex theoretical and practical-empirical debate about the objectives of a feminist or post-feminist project. It may be that a person's commitment to politics, in and of itself, does not resolve debate and reflexion as to the kind of politics which should excite such commitment. So, for example, the Padua conference echoed to many voices declaring that the work of the European Commission (along with the increasing cooperation which was thought to be developing amongst police throughout Europe) threatens to create a Fortress Europe, characterised by "hidden" and un-democratic influences, unaccountable systems of surveillance and social control, free market economic policies and a racist immigration policy. But a minority of other voices were also heard at the conference, declaring their support for a notion of a Social Europe, mobilised through the European Parliament, as a highly desirable political future compared to the alternatives on offer, in global or national terms. A part of the project of such a Europe might very well be the inter-national coordination of police action against the drug trade in the name of Social Defence, albeit such police activity ought indeed to be subject to proper accountability to European institutions; and there would undoubtedly be other areas in which inter-national cooperation across European states might be understood as being in the common good rather than a matter, self-evidently, of "repression".

In the nervous month that led to the close vote of the French people on Maastricht, it is not surprising that the conference of the European Group was rather restrained in its discussion of fundamental issues with respect to the larger project of European unification. But it is certainly to be hoped that the European Group has the desire and the capacity, in the more medium term, to take on these issues without fear or favour, and, in so doing, locate the discussion of the project of critical criminology, both constructively and critically, in terms of the rapid political, legal and social developments occurring in the larger European theatre.

\section{Notes}

1. See Karl F Schumann "Workshop Transferring Progressive Criminology in Amsterdam 26 Juni 1992 - ein Tagungsbericht" and Willem de Haan "Universalismus in der kritischen Kriminologie". Both in Kriminologische Journal, 1992.

2. For discussion of the twenty-year development of the European Group, see Rene van Swaaningen "The European Group for the Study of Deviance and Social Control: inspirations and aspirations of a critical criminology" in The Bulletin of the EGSDSC No. $3 \mathrm{pp}$. $34-46$. 
3. The interest in human rights as an area for critical criminology was first elaborated by Herman and Julia Schwendinger in 1973 (in their "Guardians of Order or Defenders of Human Rights?" in Ian Taylor et al. Critical Criminology, London: Routledge and Kegan Paul), and has been taken up at subsequent meetings of the European Group by Alessandro Baratta and others. This was the first conference of the European Group specifically devoted to the theme. 